Article

\title{
Highly Active and Isospecific Styrene Polymerization Catalyzed by Zirconium Complexes Bearing Aryl-substituted [OSSO]-Type Bis(phenolate) Ligands
}

\author{
Norio Nakata *, Tomoyuki Toda, Yusuke Saito, Takanori Watanabe and Akihiko Ishii * \\ Department of Chemistry, Graduate School of Science and Engineering, Saitama University, 255 Shimo-okubo, \\ Sakura-ku, Saitama 338-8570, Japan; t.toda@mst.nagaokaut.ac.jp (T.T.); s13ds003@mail.saitama-u.ac.jp (Y.S.); \\ s14mc129@mail.saitama-u.ac.jp (T.W.) \\ * Correspondence: nakata@chem.saitama-u.ac.jp (N.N.); ishiiaki@chem.saitama-u.ac.jp (A.I.); \\ Tel.: +81-48-858-3392 (N.N.); Fax: +81-48-858-3700 (N.N.)
}

Academic Editor: Changle Chen

Received: 17 December 2015; Accepted: 20 January 2016; Published: 26 January 2016

\begin{abstract}
OSSO]-type dibenzyl zirconium(IV) complexes $\mathbf{9}$ and $\mathbf{1 0}$ possessing aryl substituents ortho to the phenoxide moieties (ortho substituents, phenyl and 2,6-dimethylphenyl (Dmp)) were synthesized and characterized. Upon activation with dMAO (dried methylaluminoxane), complex 9 was found to promote highly isospecific styrene polymerizations ( $[\mathrm{mm}]=97.5 \%-99 \%)$ with high molecular weights $M_{\mathrm{w}}$ up to $181,000 \mathrm{~g} \cdot \mathrm{mmol}^{-1}$. When the Dmp-substituted pre-catalyst 10/dMAO system was used, the highest activity, over $7700 \mathrm{~g} \cdot \mathrm{mmol}(\mathbf{1 0})^{-1} \cdot \mathrm{h}^{-1}$, was recorded involving the formation of precisely isospecific polystyrenes of $[\mathrm{mm}]$ more than $99 \%$.
\end{abstract}

Keywords: zirconium; post-metallocene; styrene polymerization; [OSSO]-type ligand; isotactic

\section{Introduction}

Stereo-controlled polystyrene such as syndiotactic (sPS) and isotactic polystyrenes (iPS) is one of the most versatile polymeric materials, owing to its high melting point, high crystallinity, and excellent resistance to heat and chemicals [1,2]. Since the syndiospecific polymerization of styrene catalyzed by homogeneous $\mathrm{CpTiCl}_{3} / \mathrm{MAO}$ system was discovered by Ishihara and coworkers at Idemitsu Kosan (Tokyo, Japan) [3,4], numerous efforts have been devoted to employ efficient metal-based catalysts for the production of sPS [5-19]. In sharp contrast, isotactic-enriched polystyrenes are still prepared using heterogeneous catalysis [20-26] or anionic polymerization [27-30]. While many homogeneous nickel catalysts for the synthesis of iPS have been reported [31-33], there are only a few examples of metallocene and post-metallocene catalysts that produce completely isotactic polystyrene $[34,35]$. Okuda et al. reported that MAO-activated titanium complex 1a supported by 1,4-dithiabutane-bridged [OSSO]-type bis(phenolate) ligand catalyzes the styrene polymerization with good activity (330 $\mathrm{g} \cdot \mathrm{mmol}(\mathbf{1 a})^{-1} \cdot \mathrm{h}^{-1}$ ) to yield ultra-high molecular weight isotactic polystyrene $\left(M_{\mathrm{w}}=5,300,000 \mathrm{~g} \cdot \mathrm{mol}^{-1}\right)[36,37]$. Very recently, they also demonstrated that thermally stable robust zirconium complex 2 possessing a dicumyl-substituted [OSSO]-type bis(phenolate) ligand can efficiently polymerize styrene in living fashion giving highly isotactic poly(styrene) $([\mathrm{mm}]>99 \%)$ with quite high activity up to $3158 \mathrm{~g} \cdot \mathrm{mmol}(2)^{-1} \cdot \mathrm{h}^{-1}$ [38]. Capacchione and Proto et al. also presented the living isospecific polymerization of styrene and 1,3-dienes promoted by using [OSSO]-type titanium complex $\mathbf{1 b}$ and MAO to form isotactic-poly(styrene)-block-poly(1,3-diene) copolymes [39,40]. ansa-Bridged bis(indenyl) allyl yttrium and neodymium complexes 3 developed by Carpentier et al. 
also acted as single-site catalysts for the completely isospecific polymerization of styrene with relatively high activity (3a: 1066-1637 $\mathrm{g} \cdot \mathrm{mmol}(3 \mathbf{a})^{-1} \cdot \mathrm{h}^{-1} ; \mathbf{3 b}$ : 392-1094 $\left.\mathrm{g} \cdot \mathrm{mmol}(3 \mathbf{b})^{-1} \cdot \mathrm{h}^{-1}\right)[41,42]$.

Recently, we have succeeded in the development of an [OSSO]-type bis(phenolate) ligand (4) based on a trans-1,2-cyclooctanediyl platform and the preparation of several early-transition metal and aluminum complexes [43-48]. We have also found that zirconium(IV) and hafnium(IV) complexes 5 [49,50] and $\mathbf{6}$ [51] incorporating ligand 4 with activator could promote precisely isospecific polymerizations of $\alpha$-olefins such as 1-hexene, 4-methyl-1-pentene, and propylene involving excellent activity (Scheme 1). However, the polymerization of styrene using complexes $\mathbf{5}$ or $\mathbf{6}$ and activator did not occur, even at high temperatures, probably due to steric hindrance by bulky $t$ Bu groups at the ortho positions on the phenolate moieties in 4 . These results encouraged us to develop a new type of [OSSO]-type bis(phenolate) ligands, which have a suitable coordination environment to achieve the isospecific styrene polymerization. Herein, we present the synthesis and structural characterization of [OSSO]-type dibenzyl zirconium(IV) complexes possessing aryl substituents ortho to the phenoxide moieties, as well as their ability to catalyze isospecific styrene polymerization.

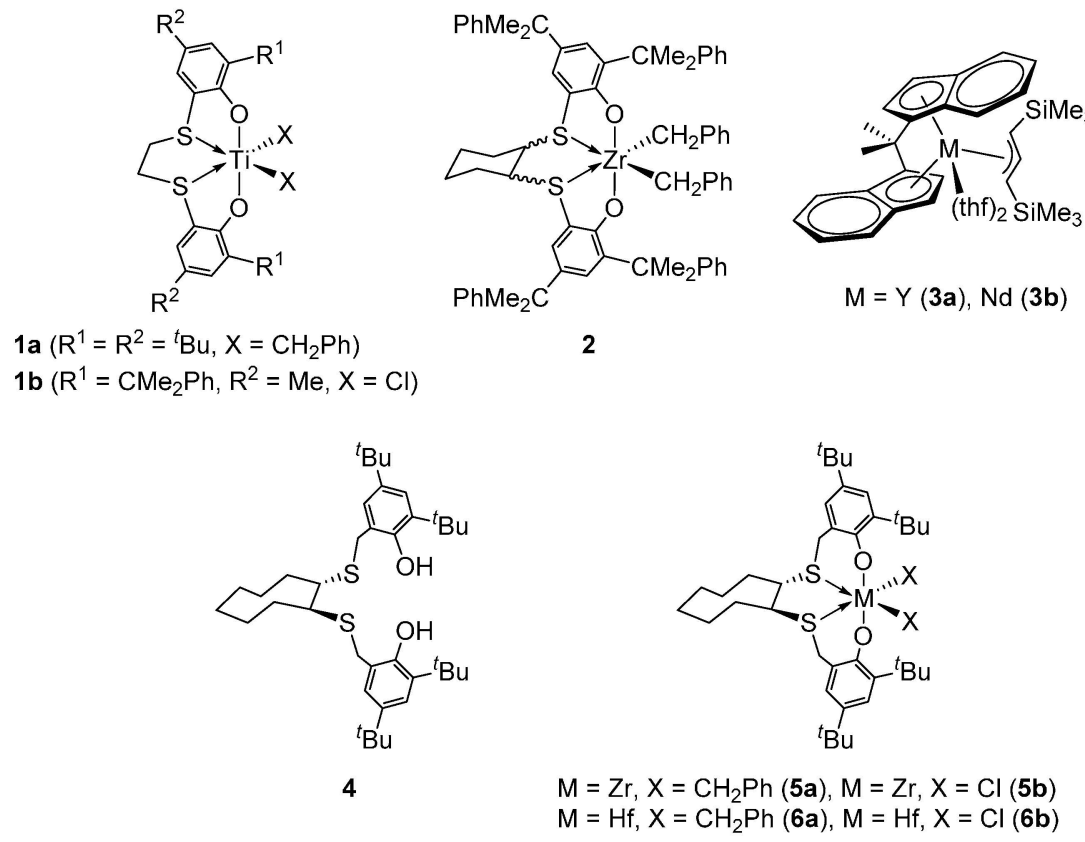

Scheme 1. Related post-metallocene complexes 1-3 for styrene polymerization, [OSSO]-type ligand 4 and its complexes 5 and $\mathbf{6}$.

\section{Experimental Section}

\subsection{General}

All manipulations of air- and/or moisture-sensitive compounds were performed either using standard Schlenk-line techniques or in UNICO 650F (Ibaraki, Japan) or Glovebox Japan E300 gloveboxes (Tokyo, Japan) under an inert atmosphere of argon. Hexane and toluene were purchased from Kanto Chemical (Tokyo, Japan) and were dried over a potassium mirror prior to use. $\mathrm{C}_{6} \mathrm{D}_{6}$ was dried over a potassium mirror, and it was degassed by a freeze-thaw cycle prior to use. ${ }^{1} \mathrm{H}$ and ${ }^{13} \mathrm{C}$ NMR spectra were recorded on a Bruker DPX-400 (400 and $101 \mathrm{MHz}$, respectively, (Billerica, MA, USA) using $\mathrm{CDCl}_{3}$ or $\mathrm{C}_{6} \mathrm{D}_{6}$ as the solvent at room temperature. High-resolution mass spectrometry (HRMS) data were recorded by using a Hitachi-Hitec NanoFrontier eLD (Tokyo, Japan). All melting points were determined on a Mel-Temp capillary tube apparatus (Saitama, Japan) and are uncorrected. The molecular weights $\left(M_{\mathrm{w}}\right)$ and molecular weight distributions $\left(M_{\mathrm{w}} / M_{\mathrm{n}}\right)$ of the polymers were evaluated by gel permeation chromatography (GPC) on a SCL-10AVP/LC-10ATVP/DGU-14A/ 
CTO-10ACVP/RID-10A apparatus (Shimadzu Corporation, Kyoto, Japan) using a GPC KF-804L (Shodex Corporation, Tokyo, Japan) column. The analyses were performed at room temperature using THF as the solvent and standard polystyrene as the reference. Differential scanning calorimetry (DSC) analyses were performed on a Seiko Instruments DSC 6200 apparatus (Tokyo, Japan) at a rate of $5{ }^{\circ} \mathrm{C} / \mathrm{min}$, under continuous flow of $\mathrm{N}_{2}(0.5 \mathrm{~mL} / \mathrm{min})$, using aluminum capsules. [OSSO]-type ancillary ligands 7 and 8 [53] and dMAO [54] were prepared by the literature procedures.

\subsection{Preparation of Dibenzyl Zirconium(IV) Complex 9}

A solution of $7(298 \mathrm{mg}, 0.430 \mathrm{mmol})$ in toluene $(10 \mathrm{~mL})$ was added to a solution of $\mathrm{Zr}\left(\mathrm{CH}_{2} \mathrm{Ph}\right)_{4}$ [55] $(196 \mathrm{mg}, 0.430 \mathrm{mmol})$ in toluene $(10 \mathrm{~mL})$ at room temperature. The mixture was stirred for $1 \mathrm{~h}$ at room temperature, and the solvent was removed under reduced pressure. The residue was washed with hexane and dried in vacuo to give dibenzyl zirconium(IV) complex $9(346 \mathrm{mg})$ in $83 \%$ yield as yellow crystals. 9: $\mathrm{Mp} 274-275{ }^{\circ} \mathrm{C}$ (dec.).

${ }^{1} \mathrm{H}$ NMR $(400 \mathrm{MHz}) \delta 0.65$ (br s, 2H), 0.91 (br s, 2H), 1.07 (br s, 6H), 1.29-1.41 (m, 6H), $1.38(\mathrm{~d}$, $J=9 \mathrm{~Hz}, 2 \mathrm{H}), 2.01(\mathrm{~d}, J=9 \mathrm{~Hz}, 2 \mathrm{H}), 2.39(\mathrm{br} \mathrm{s}, 2 \mathrm{H}), 3.15(\mathrm{~d}, J=14 \mathrm{~Hz}, 2 \mathrm{H}), 3.35(\mathrm{~d}, J=14 \mathrm{~Hz}, 2 \mathrm{H}), 6.50$ $(\mathrm{d}, J=7 \mathrm{~Hz}, 4 \mathrm{H}), 6.88(\mathrm{~d}, J=2 \mathrm{~Hz}, 2 \mathrm{H}), 6.96-7.21(\mathrm{~m}, 14 \mathrm{H}), 7.34-7.40(\mathrm{~m}, 8 \mathrm{H}), 7.54(\mathrm{~d}, J=2 \mathrm{~Hz}, 2 \mathrm{H})$, $7.67(\mathrm{~d}, J=7 \mathrm{~Hz}, 4 \mathrm{H})$.

${ }^{13} \mathrm{C}\left\{{ }^{1} \mathrm{H}\right\} \mathrm{NMR}(101 \mathrm{MHz}) \delta 25.4\left(\mathrm{CH}_{2}\right), 26.1\left(\mathrm{CH}_{2}\right), 28.7\left(\mathrm{CH}_{2}\right), 34.5\left(\mathrm{CH}_{2}\right), 48.5(\mathrm{CH}), 59.3\left(\mathrm{CH}_{2}\right)$, $123.1(\mathrm{C}), 123.3(\mathrm{CH}), 127.0(2 \mathrm{CH}), 127.6(\mathrm{CH}), 128.6(\mathrm{CH}), 128.7(\mathrm{CH}), 129.1(2 \mathrm{CH}), 129.2(2 \mathrm{CH}), 129.3$ $(2 \mathrm{CH}), 129.9(2 \mathrm{CH}), 130.5(\mathrm{CH}), 130.8(2 \mathrm{CH}), 132.5(\mathrm{C}), 133.3(\mathrm{C}), 140.1(\mathrm{C}), 141.1(\mathrm{C}), 144.4(\mathrm{C}), 158.2(\mathrm{C})$.

\subsection{Preparation of Dibenzyl Zirconium(IV) Complex 10}

A solution of 8 ( $380 \mathrm{mg}, 0.608 \mathrm{mmol})$ in toluene $(10 \mathrm{~mL})$ was added to a solution of $\mathrm{Zr}\left(\mathrm{CH}_{2} \mathrm{Ph}\right)_{4}$ [55] $(277 \mathrm{mg}, 0.608 \mathrm{mmol})$ in toluene $(5 \mathrm{~mL})$ at room temperature. The mixture was stirred for $1 \mathrm{~h}$ at room temperature, and the solvent was removed under reduced pressure. The residue was washed with hexane $(2 \mathrm{~mL})$ and dried to give dibenzyl zirconium(IV) complex $10(499 \mathrm{mg}, 92 \%)$ as yellow crystals. 10: $\mathrm{Mp} 240-241^{\circ} \mathrm{C}$ (dec.).

${ }^{1} \mathrm{H}$ NMR $\left(400 \mathrm{MHz}, \mathrm{C}_{6} \mathrm{D}_{6}\right) \delta 0.76(\mathrm{~m}, 2 \mathrm{H}), 0.82(\mathrm{~d}, J=8 \mathrm{~Hz}, 2 \mathrm{H}), 1.00(\mathrm{~m}, 2 \mathrm{H}), 1.17-1.30(\mathrm{~m}, 6 \mathrm{H})$, 1.45-1.55 (m, 4H), $1.65(\mathrm{~d}, J=8 \mathrm{~Hz}, 2 \mathrm{H}), 2.05(\mathrm{~s}, 6 \mathrm{H}), 2.10(\mathrm{~s}, 1 \mathrm{H}), 2.26(\mathrm{~s}, 6 \mathrm{H}), 2.38(\mathrm{~s}, 6 \mathrm{H}), 2.41(\mathrm{br} \mathrm{s}$, $1 \mathrm{H}), 3.04(\mathrm{~d}, J=15 \mathrm{~Hz}, 2 \mathrm{H}), 3.11(\mathrm{~d}, J=15 \mathrm{~Hz}, 2 \mathrm{H}), 6.33(\mathrm{br} \mathrm{s}, 2 \mathrm{H}), 6.47(\mathrm{~d}, J=7 \mathrm{~Hz}, 4 \mathrm{H}), 6.71(\mathrm{br} \mathrm{s}, 2 \mathrm{H})$, $6.91(\mathrm{t}, J=7 \mathrm{~Hz}, 2 \mathrm{H}), 7.07(\mathrm{t}, J=7 \mathrm{~Hz}, 4 \mathrm{H}), 7.11-7.15(\mathrm{~m}, 4 \mathrm{H}), 7.25(\mathrm{~d}, J=7 \mathrm{~Hz}, 2 \mathrm{H})$.

${ }^{13} \mathrm{C}\left\{{ }^{1} \mathrm{H}\right\} \mathrm{NMR}\left(101 \mathrm{MHz}, \mathrm{C}_{6} \mathrm{D}_{6}\right) \delta 20.6\left(\mathrm{CH}_{3}\right), 21.3\left(\mathrm{CH}_{3}\right), 21.4\left(\mathrm{CH}_{3}\right), 21.9\left(\mathrm{CH}_{2}\right), 25.4\left(\mathrm{CH}_{2}\right), 26.2$ $\left(\mathrm{CH}_{2}\right), 34.3\left(\mathrm{CH}_{2}\right), 48.1(\mathrm{CH}), 58.0\left(\mathrm{CH}_{2}\right), 122.0(\mathrm{C}), 122.8(\mathrm{CH}), 127.6(\mathrm{CH}), 127.8(\mathrm{CH}), 127.9(\mathrm{CH}), 129.2$ $(2 \mathrm{CH}), 129.3(\mathrm{C}), 129.6(2 \mathrm{CH}), 130.2(\mathrm{CH}), 130.8(\mathrm{C}), 131.4(\mathrm{CH}), 136.2(\mathrm{C}), 137.4(\mathrm{C}), 139.9(\mathrm{C}), 144.6(\mathrm{C})$, $156.1(C)$.

\subsection{General Procedure for Styrene Polymerization}

A $50 \mathrm{~mL}$ Schlenk-flask was charged sequentially with catalytic precursor 9 or $\mathbf{1 0}(2.0 \mu \mathrm{mol})$, dMAO as an activator $(0.50 \mathrm{mmol})$, and toluene $(5 \mathrm{~mL})$ at $25^{\circ} \mathrm{C}$. After stirring for $5 \mathrm{~min}$ at the temperature, styrene $(3.0 \mathrm{~g}, 28.8 \mathrm{mmol})$ was added to the reaction mixture. The mixture was stirred for 60,10 , or $5 \mathrm{~min}$ at a desired temperature. The reaction was quenched by addition of methanol and $\mathrm{HCl}$ aq. The mixture was extracted with $\mathrm{CH}_{2} \mathrm{Cl}_{2}$ and the organic layer was washed with water and dried over anhydrous $\mathrm{Na}_{2} \mathrm{SO}_{4}$. The solvent was removed in vacuo at $70{ }^{\circ} \mathrm{C}$ during overnight to leave poly(styrene).

\subsection{X-ray Crystallographic Analysis}

Yellow single crystals of 9 were grown by slow evaporation of its saturated hexane solution at $-20^{\circ} \mathrm{C}$. The intensity data were collected at $100 \mathrm{~K}$ for 9 on a Bruker SMART APEX II ULTRA (Billerica, MA, USA) equipped with a CCD area detector with graphite-monochromated MoKa radiation $(l=0.71073 \AA$ ). The structure was solved by direct methods and refined by full-matrix least-squares procedures on $F^{2}$ for all reflections (SHELX-97) [56]. Hydrogen atoms of 9 were located by assuming 
ideal geometry and were included in the structure calculations without further refinement of the parameters. Crystallographic data and details of refinement for 9: $\mathrm{C}_{60} \mathrm{H}_{56} \mathrm{O}_{2} \mathrm{~S}_{2} \mathrm{Zr}, 2\left(\mathrm{C}_{7} \mathrm{H}_{8}\right)$, $M_{\mathrm{W}}=1148.66$, orthorhombic, space group $P 2{ }_{1} 2{ }_{1} 2_{1}, a=11.8318(11) \AA, b=21.988(2) \AA, c=22.933(2) \AA$, $V=5966.1(10) \AA^{3}, Z=4, D_{\text {calc }}=1.279 \mathrm{~g} \mathrm{~cm}^{-3}, R_{1}(I>2 \sigma I)=0.0434, w R_{2}$ (all data) $=0.1053$ for 11081 reflections, 495 restraints, and 833 parameters, $\mathrm{GOF}=1.017$.

\section{Results and Discussion}

\subsection{Synthesis of Dibenzyl Zirconium(IV) Complexes $\mathbf{9}$ and $\mathbf{1 0}$}

According to a previous report [53], new [OSSO]-type ancillary ligands 7 and 8 with ortho, para-diphenylphenol or ortho-2,6-dimethylphenyl (Dmp), para-methylphenol substituents, respectively, were prepared in the total yields of $45 \%$ or $39 \%$, respectively. Treatment of [OSSO]-type ligands 7 or 8 with $\mathrm{Zr}\left(\mathrm{CH}_{2} \mathrm{Ph}\right)_{4}$ in toluene at room temperature gave the corresponding dibenzyl zirconium(IV) complexes 9 or $\mathbf{1 0}$ as air- and moisture-sensitive pale yellow crystals in $83 \%$ or $92 \%$ yields, respectively (Scheme 2). Similarly to the NMR observation of the related [OSSO]-type dibenzyl zirconium(IV) complex 5 [49,50], all NMR data of $\mathbf{9}$ and $\mathbf{1 0}$ showed the magnetical equivalency of two phenolate moieties as well as the two benzyl ligands, indicating that complexes $\mathbf{9}$ and $\mathbf{1 0}$ take a $C_{2}$-symmetric, helical structure on the NMR time scale. For example, in the ${ }^{1} \mathrm{H} N \mathrm{NM}, \mathrm{AB}$ patterns due to the $S$-benzyl protons appeared at $\delta 3.15$ and 3.34 with $J=14 \mathrm{~Hz}$ for 9 and at $\delta 3.04$ and 3.11 with $J=15 \mathrm{~Hz}$ for $\mathbf{1 0}$. The sulfur-bonded methine protons in the cyclooctane ring were observed at $\delta 2.39$ for 9 and $\delta 2.41$ for 10 as a broad singlet.
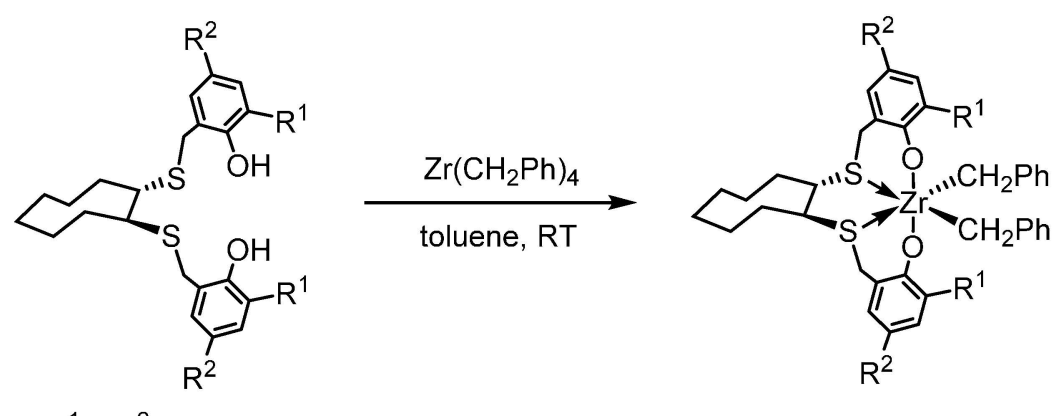

$$
\begin{aligned}
& 7\left(R^{1}=R^{2}=P h\right) \\
& 8\left(R^{1}=D m p, R^{2}=M e\right)
\end{aligned}
$$$$
9(83 \%)
$$$$
10(92 \%)
$$

Scheme 2. Synthesis of aryl-substituted [OSSO]-type dibenzyl zirconium(IV) complexes $\mathbf{9}$ and 10.

The molecular structure of diphenyl derivative 9 was confirmed by X-ray crystallography, as shown in Figure 1. In the crystalline state, the zirconium center possesses a distorted octahedral geometry with cis-arranged two sulfur atoms and two benzyl groups, adopting a cis- $\alpha$ configuration as similar as the previously reported [OSSO]-type zirconium(IV) complexes [49,50,57-60]. One benzyl ligand of 9 is coordinated to the zirconium center by $\eta^{1}$-mode with the $\mathrm{Zr}-\mathrm{C}_{\mathrm{benzyl}}-\mathrm{C}_{\mathrm{ipso}}$ angle of $124.3(2)^{\circ}$, whereas the other has an acute $\mathrm{Zr}-\mathrm{C}_{\text {benzyl }}-\mathrm{C}_{\text {ipso }}$ angle of $84.4(2)^{\circ}$ consistent with the $\eta^{2}$-coordination fashion as similarly as in the case of $t$ Bu-substituted complex $5 \mathbf{a}$; the $\mathrm{Zr}-\mathrm{C}_{\text {ipso }}$

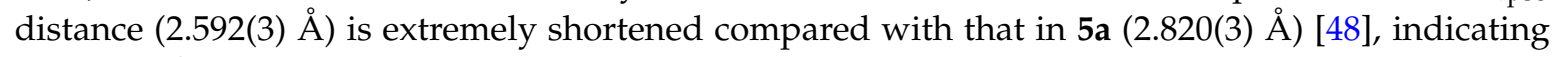
that this $\eta^{2}$-benzyl group in $\mathbf{9}$ is strongly bound to the metal than that in $5 \mathbf{a}$ due to the less steric hindrance around the zirconium center in 9 as expected. The $\mathrm{Zr}-\mathrm{S}$ bond lengths in 9 (2.8073(7), $2.8148(11) \AA$ ) are comparable to those in $5 \mathbf{a}(2.8107(8), 2.7682(8) \AA)[49,50]$ and $\left[\mathrm{Zr}\left\{2,2^{\prime}-\left(\mathrm{OC}_{6} \mathrm{H}_{2}-4,6-\mathrm{Br}_{2}\right)_{2}\right.\right.$ $\left.\mathrm{CH}_{2} \mathrm{SCH}_{2} \mathrm{CH}_{2} \mathrm{SCH}_{2}\right\}\left(\mathrm{CH}_{2} \mathrm{Ph}\right)_{2}$ ] (2.7934(7), 2.7932(6) $\AA$ ) [61]. 


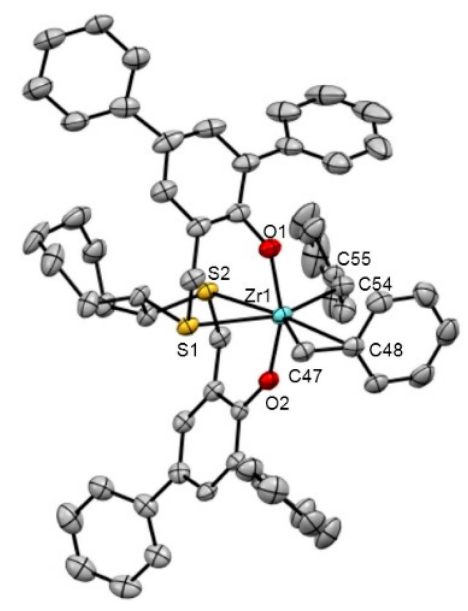

Figure 1. ORTEP drawing of dibenzyl zirconium(IV) complex 9 (50\% thermal ellipsoids, hydrogen atoms and solvated toluene molecules were omitted for clarity). Selected bond lengths $\AA$ and bond angles ${ }^{\circ}: \mathrm{Zr1}-\mathrm{O} 1=1.998$ (2), Zr1-O2 = 2.005 (2), Zr1-C47 = 2.305 (3), Zr1-C48 = 2.592 (3), Zr1-C54 = 2.321 (4), Zr1-S1 = 2.8148 (11), Zr1-S2 = 2.8079 (9), O1-Zr1-O2 = 160.25 (9), S1-Zr1-S2 = 70.74 (3), C47-Zr1-C54 = 121.54 (13), Zr1-C47-C48 = 84.4 (2), Zr1-C54-C55 = 124.3 (3), $\mathrm{S} 1-\mathrm{C} 1-\mathrm{C} 2-\mathrm{S} 2=67.3$ (3).

\subsection{Styrene Polymerization}

To elucidate the potential as an isospecific polymerization catalyst, we examined the coordinate polymerization of styrene using precursors 9 and 10. The results at varied temperatures are compiled in Table 1. The polymerization of styrene $(3.0 \mathrm{~g}, 28.8 \mathrm{mmol})$ with $9(2.0 \mu \mathrm{mol})$ upon activation with 250 equiv. of $\mathrm{dMAO}(500 \mu \mathrm{mol})$ in toluene at $0{ }^{\circ} \mathrm{C}$ proceeded slowly to yield a crystalline polystyrene $(0.099 \mathrm{~g})$ (Run 1). The microstructure of the polystyrene was determined by ${ }^{13} \mathrm{C}$ NMR spectroscopy, which showed six sharp signals to mean an excellent isotacticity over $99 \%$ of the $[\mathrm{mm}]$ triad (Figure 2). Since no stereo error was observed around the lowest resonance at $\delta 146.3$ assigned to the phenyl ipso carbon, the detail microstructure is attributed to the $[\mathrm{mm}]$ heptad. Similarly to the case for ansa-type complexes 3 reported by Carpentier [41,42], an enantiomorphic site control mechanism is operating for the stereospecific propagation in our system, probably due to the racemic coordination of the [OSSO]-type ligand framework. This high isotactic microstructure can be corroborated from the melting temperature $\left(T_{\mathrm{m}}=218.6^{\circ} \mathrm{C}\right)$ determined by DSC analysis. The GPC analysis of the resulting polymer revealed a large molecular weight $\left(M_{\mathrm{W}}=137,000 \mathrm{~g} \cdot \mathrm{mol}^{-1}\right)$ and a monomodal distribution with a very broad polydispersity $(\mathrm{PDI}=8.6)$. When the polymerization temperature was raised to 25 or $40{ }^{\circ} \mathrm{C}$, slightly decreasing isotacticity of $96.8 \%$ or $90.7 \%$ together with narrower molecular weight distributions of 3.8 or 2.9 were observed, respectively (Runs 2 and 3). At $70{ }^{\circ} \mathrm{C}, 9 / \mathrm{dMAO}$ system showed the highest activity of $618 \mathrm{~g} \cdot \mathrm{mmol}(9)^{-1} \cdot \mathrm{h}^{-1}$, and the narrow PDI value of 2.2 , while the isotacticity of the obtained polymer decreased somewhat to $87.5 \%$ and the molecular weight $M_{\mathrm{w}}$ was reduced drastically to $9500 \mathrm{~g} \cdot \mathrm{mol}^{-1}$, suggesting that the active species was unstable during the chain propagation step at high temperatures (Run 4). In the varying temperature experiments, the broader polydispersity and the higher molecular weight $M_{\mathrm{W}}$ were observed at lower temperatures as characteristic trends. These results would be explained by a relatively slow generation of active species and/or a slow propagation of polymer chains in the styrene polymerization process.

We then turned our attention to the use of Dmp-substituted complex 10. The polymerization of styrene $(3.0 \mathrm{~g}, 28.8 \mathrm{mmol})$ employing the system consisting of $\mathbf{1 0}(2.0 \mu \mathrm{mol})$ and dMAO $(500 \mu \mathrm{mol})$ in toluene at $0{ }^{\circ} \mathrm{C}$ for $10 \mathrm{~min}$ could also afford completely isotactic polystyrene of $0.259 \mathrm{~g}([\mathrm{~mm}]$ $>99 \%$ ), which corresponds to the activity of $777 \mathrm{~g} \cdot \mathrm{mmol}(\mathbf{1 0})^{-1} \cdot \mathrm{h}^{-1}$ (Run 5). Despite the more overcrowded environment at zirconium center in 10, this activity is approximately 15 times higher 
than that of 9 at the same temperature $\left(50 \mathrm{~g} \cdot \mathrm{mmol}(\mathbf{9})^{-1} \cdot \mathrm{h}^{-1}\right)$. GPC analysis exhibited that the obtained polymer was monomodal and had a high molecular weight $\left(M_{\mathrm{w}}=257,000 \mathrm{~g} \cdot \mathrm{mol}^{-1}\right)$ and a slightly large polydispersity of 3.1. Similar results were observed in the polymerizations carried out at 25 and $40{ }^{\circ} \mathrm{C}$ to produce excellent isotactic polymers $([\mathrm{mm}]>99 \%)$ with higher molecular weights $M_{\mathrm{w}}$ up to $380,000 \mathrm{~g} \cdot \mathrm{mol}^{-1}$ and narrower molecular weight distributions of 1.8 and 2.1, respectively, being consistent with a single site behavior (Runs 6 and 7). The corresponding activities recorded in the range of $2200-4100 \mathrm{~g} \cdot \mathrm{mmol}(10)^{-1} \cdot \mathrm{h}^{-1}$ increased with elevating temperatures; at $70{ }^{\circ} \mathrm{C}, 10 / \mathrm{dMAO}$ system achieved the highest polymerization activity of $7700 \mathrm{~g} \cdot \mathrm{mmol}(\mathbf{1 0})^{-1} \cdot \mathrm{h}^{-1}$ forming a high molecular weight polystyrene $\left(M_{\mathrm{W}}=195,000 \mathrm{~g} \cdot \mathrm{mol}^{-1}\right.$, Run 8). Despite the higher polymerization temperature, the resulting polymer had a complete isotacticity $([\mathrm{mm}]>99 \%)$ and a monomodal molecular weight distribution $\left(M_{\mathrm{w}} / M_{\mathrm{n}}=1.8\right)$. In the DSC measurement, the melting temperatures $\left(T_{\mathrm{m}}=221.4-225.8^{\circ} \mathrm{C}\right)$ of polymers produced by $10 / \mathrm{dMAO}$ system reflected their highly isotactic microstructures. Thus, our catalyst system exhibited remarkably higher activity, even at low temperatures $\left(777-7700 \mathrm{~g} \cdot \mathrm{mmol}(\mathbf{1 0})^{-1} \cdot \mathrm{h}^{-1}\right.$ at $\left.0-70{ }^{\circ} \mathrm{C}\right)$ than those of reported [OSSO]-type titanium complex 1a (330 g. mmol $(\mathbf{1})^{-1} \cdot \mathrm{h}^{-1}$ at $\left.40^{\circ} \mathrm{C}\right)$ [8] and ansa-type yttrium and neodymium complexes $3 \mathbf{a}$ $\left(1066-1637 \mathrm{~g} \cdot \mathrm{mmol}(\mathrm{cat})^{-1} \cdot \mathrm{h}^{-1}\right.$ at $\left.80-120^{\circ} \mathrm{C}\right)$ and $3 \mathbf{b}\left(392-1094 \mathrm{~g} \cdot \mathrm{mmol}(\mathrm{cat})^{-1} \cdot \mathrm{h}^{-1}\right.$ at $\left.60-100{ }^{\circ} \mathrm{C}\right)$ [11].

Table 1. Styrene polymerization with dibenzyl zirconium(IV) complexes $\mathbf{9}$ and $\mathbf{1 0}$ upon activation with dMAO.

\begin{tabular}{|c|c|c|c|c|c|c|c|c|}
\hline Run & Cat. & $\begin{array}{l}\text { Temp. } \\
\left({ }^{\circ} \mathrm{C}\right)\end{array}$ & $\begin{array}{l}\text { Time } \\
(\mathrm{min})\end{array}$ & $\begin{array}{c}\text { Activity } \\
\left(\mathrm{g} \cdot \mathrm{mmol}^{-1} \cdot \mathbf{h}^{-1}\right)\end{array}$ & $\begin{array}{c}M_{\mathrm{w}} \\
\left(\mathrm{g} \cdot \mathrm{mol}^{-1}\right)\end{array}$ & $\mathbf{P D I}^{b}$ & $\begin{array}{c}(m m)^{c} \\
(\%)\end{array}$ & $\begin{array}{l}T_{\mathrm{m}}{ }^{d} \\
\left({ }^{\circ} \mathrm{C}\right)\end{array}$ \\
\hline 1 & 9 & 0 & 60 & 50 & 137,000 & 8.6 & $>99$ & 218.6 \\
\hline 2 & 9 & 25 & 60 & 139 & 156,000 & 3.8 & 96.8 & 209.8 \\
\hline 3 & 9 & 40 & 60 & 182 & 181,000 & 2.9 & 90.7 & - \\
\hline 4 & 9 & 70 & 60 & 618 & 9500 & 2.2 & 87.5 & - \\
\hline 5 & 10 & 0 & 10 & 777 & 257,000 & 3.1 & $>99$ & 225.3 \\
\hline 6 & 10 & 25 & 10 & 2200 & 380,000 & 2.1 & $>99$ & 225.8 \\
\hline 7 & 10 & 40 & 5 & 4100 & 338,000 & 1.8 & $>99$ & 222.6 \\
\hline 8 & 10 & 70 & 5 & 7700 & 195,000 & 1.8 & $>99$ & 221.4 \\
\hline
\end{tabular}

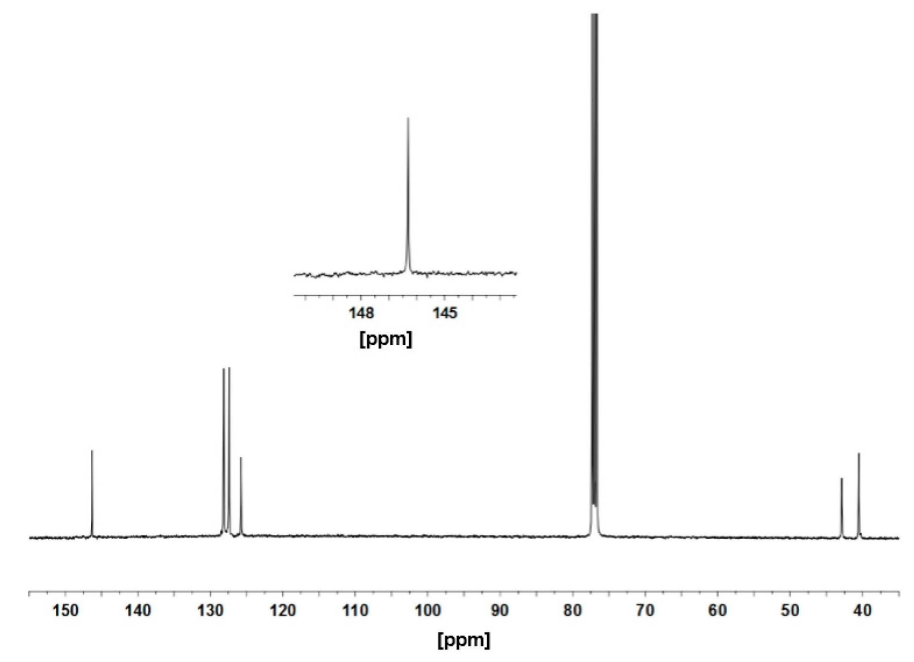

Figure 2. ${ }^{13} \mathrm{C}\left\{{ }^{1} \mathrm{H}\right\}$ NMR spectrum of polystyrene obtained by the $9 / \mathrm{dMAO}$ system at $0{ }^{\circ} \mathrm{C}$ (Table 1 , Run 1). 


\section{Conclusions}

We have established a controlled isospecific polymerization of styrene employing dibenzyl zirconium(IV) complexes (9 and 10) supported by new aryl-substituted [OSSO]-type bis(phenolate) ligands based on trans-cyclooctanediyl platform. Use of the Dmp-substituted pre-catalyst 10 in the presence of dMAO as an activator was critical for the formation of precisely isospecific polystyrenes with high activities. Notably, the isotactic polymers produced by $\mathbf{1 0 / d M A O}$ system had significantly larger molecular weights and narrower polydispersity indexes of nearly 2.0.

Supplementary Materials: Supplementary materials can be accessed at www.mdpi.com/2073-4360/8/2/31/s1. Figure S1. ${ }^{1} \mathrm{H}-\mathrm{NMR}$ spectrum of dibenzyl zirconium(IV) complex 9; Figure S2. ${ }^{1} \mathrm{H}-\mathrm{NMR}$ spectrum of dibenzyl zirconium(IV) complex 10; Figure S3. ${ }^{13} \mathrm{C}\left\{{ }^{1} \mathrm{H}\right\}$-NMR spectrum of polystyrene obtained by the 10/dMAO system at $0{ }^{\circ} \mathrm{C}$ (Table 1, Run 5); Figure $S 4 .{ }^{13} \mathrm{C}\left\{{ }^{1} \mathrm{H}\right\}$-NMR spectrum of polystyrene obtained by the $10 / \mathrm{dMAO}$ system at $25{ }^{\circ} \mathrm{C}$ (Table 1, Run 6); Figure S5. ${ }^{13} \mathrm{C}\left\{{ }^{1} \mathrm{H}\right\}$-NMR spectrum of polystyrene obtained by the $10 / \mathrm{dMAO}$ system at $40{ }^{\circ} \mathrm{C}$ (Table 1, Run 7); Figure S6. ${ }^{13} \mathrm{C}\left\{{ }^{1} \mathrm{H}\right\}-\mathrm{NMR}$ spectrum of polystyrene obtained by the $10 / \mathrm{dMAO}$ system at $70{ }^{\circ} \mathrm{C}$ (Table 1, Run 8); Figure S7. DSC chart of polystyrene obtained by the $10 / \mathrm{dMAO}$ system at $0{ }^{\circ} \mathrm{C}$ (Table 1 , Run 5); Figure S8. DSC chart of polystyrene obtained by the $10 / \mathrm{dMAO}$ system at $25^{\circ} \mathrm{C}$ (Table 1, Run 6); Figure S9. DSC chart of polystyrene obtained by the $10 / \mathrm{dMAO}$ system at $40^{\circ} \mathrm{C}$ (Table 1, Run 7); Figure S10. DSC chart of polystyrene obtained by the $10 / \mathrm{dMAO}$ system at $70^{\circ} \mathrm{C}$ (Table 1, Run 8 ); Scheme S1. Preparation of dibenzyl zirconium(IV) complex 9; Scheme S2. Preparation of dibenzyl zirconium(IV) complex 10.

Acknowledgments: This work was supported by Grants-in-Aid (No. 23750034 to Norio Nakata) from the Ministry of Education, Culture, Sports, Science, and Technology (MEXT), Japan. Norio Nakata is thankful for financial support from the Japan Petroleum Institute and Tokuyama Science Foundation. Tomoyuki Toda acknowledges a JSPS fellowship for young scientists.

Author Contributions: Tomoyuki Toda, Yusuke Saito, and Takanori Watanabe contributed to the synthesis, polymerization, and data analysis; Norio Nakata performed X-ray crystallography and wrote the manuscript; and Norio Nakata and Akihiko Ishii proposed idea on the design of the experiment, reviewed and approved the final manuscript.

Conflicts of Interest: The authors declare no conflicts of interest.

\section{References}

1. Tomotsu, N.; Ishihara, N.; Newman, T.H.; Malanga, M.T. Syndiospecific polymerization of styrene. J. Mol. Catal. A 1998, 128, 167-190. [CrossRef]

2. Malanga, M. Syndiotactic polystyrene materials. Adv. Mater. 2000, 12, 1869-1872. [CrossRef]

3. Ishihara, N.; Kuramoto, M.; Uoi, M.; (to Idemitsu Kosan Co. Ltd.). Japanese Patent 62187708, 1985.

4. Ishihara, N.; Seimiya, T.; Kuramoto, M.; Uoi, M. Crystalline syndiotactic polystyrene. Macromolecules 1986, 19, 2464-2465. [CrossRef]

5. Luo, Y.; Baldamus, J.; Hou, Z. Scandium half-metallocene-catalyzed syndiospecific styrene polymerization and styrene-ethylene copolymerization: Unprecedented incorporation of syndiotactic styrene-styrene sequences in styrene-ethylene copolymers. J. Am. Chem. Soc. 2004, 126, 13910-13911. [CrossRef] [PubMed]

6. Kirillov, E.; Lehmann, C.W.; Razavi, A.; Carpentier, J.-F. Highly syndiospecific polymerization of styrene catalyzed by allyl lanthanide complexes. J. Am. Chem. Soc. 2004, 126, 12240-12241. [CrossRef] [PubMed]

7. Rodrigues, A.-S.; Kirillov, E.; Lehmann, C.W.; Roisnel, T.; Vuillemin, B.; Razavi, A.; Carpentier, J.-F. Allyl ansa-lanthanidocenes: Single-component, single-site catalysts for controlled syndiospecific styrene and styrene-ethylene (co)polymerization. Chem. Eur. J. 2007, 13, 5548-5565. [CrossRef] [PubMed]

8. Rodrigues, A.-S.; Kirillov, E.; Vuillemin, B.; Razavi, A.; Carpentier, J.-F. Binary ansa-lanthanidocenes / dialkylmagnesium systems versus single-component catalyst: Controlled synthesis of end-capped syndiotactic oligostyrenes. J. Mol. Catal. A 2007, 273, 87-91. [CrossRef]

9. Jaroschik, F.; Shima, T.; Li, X.; Mori, K.; Ricard, L.; Le Goff, X.-F.; Nief, F.; Hou, Z. Synthesis, characterization, and reactivity of mono(phospholyl) lanthanoid(III) bis(dimethylaminobenzyl) complexes. Organometallics 2007, 26, 5654-5660. [CrossRef]

10. Nishiura, M.; Mashiko, T.; Hou, Z. Synthesis and styrene polymerisation catalysis of $\eta^{5}-$ and $\eta^{1}$-pyrrolyl-ligated cationic rare earth metal aminobenzyl complexes. Chem. Commun. 2008, 2019-2021. [CrossRef] [PubMed] 
11. Fang, X.; Li, X.; Hou, Z.; Assoud, J.; Zhao, R. 1,2-Azaborolyl-ligated half-sandwich complexes of scandium(III) and lutetium(III): Synthesis, structures, and syndiotactic polymerization of styrene. Organometallics 2009, 28, 517-522. [CrossRef]

12. $\mathrm{Xu}, \mathrm{X}$.; Chen, Y.; Sun, J. Indenyl abstraction versus alkyl abstraction of [(Indenyl) $\mathrm{ScR}_{2}($ thf $\left.)\right]$ by $\left[\mathrm{Ph}_{3} \mathrm{C}\right]$ $\left[\mathrm{B}\left(\mathrm{C}_{6} \mathrm{~F}_{5}\right)_{4}\right]$ : Aspecific and syndiospecific styrene polymerization. Chem. Eur. J. 2009, 15, 846-850. [CrossRef] [PubMed]

13. Bonnet, F.; Violante, C.D.C.; Roussel, P.; Mortreux, A.; Visseaux, M. Unprecedented dual behaviour of a half-sandwich scandium-based initiator for both highly selective isoprene and styrene polymerisation. Chem. Commun. 2009, 3380-3382. [CrossRef] [PubMed]

14. Perrin, L.; Sarazin, Y.; Kirillov, E.; Carpentier, J.-F.; Maron, L. On the initiation mechanism of syndiospecific styrene polymerization catalyzed by single-component ansa-lanthanidocenes. Chem. Eur. J. 2009, 15, 3773-3783. [CrossRef] [PubMed]

15. Liu, D.; Luo, Y.; Gao, W.; Cui, D. Stereoselective polymerization of styrene with cationic scandium precursors bearing quinolyl aniline ligands. Organometallics 2010, 29, 1916-1923. [CrossRef]

16. Li, X.; Nishiura, M.; Hu, L.; Mori, K.; Hou, Z. Alternating and random copolymerization of isoprene and ethylene catalyzed by cationic half-sandwich scandium alkyls. J. Am. Chem. Soc. 2009, 131, 13870-13882. [CrossRef] [PubMed]

17. Guo, F.; Nishiura, M.; Koshino, H.; Hou, Z. Scandium-catalyzed cyclocopolymerization of 1,5-hexadiene with styrene and ethylene: Efficient synthesis of cyclopolyolefins containing syndiotactic styrene-styrene sequences and methylene-1,3-cyclopentane units. Macromolecules 2011, 44, 6335-6344. [CrossRef]

18. Pan, L.; Zhang, K.; Nishiura, M.; Hou, Z. Syndiospecific living copolymerization of styrene with $\varepsilon$-caprolactone by scandium catalysts. Macromolecules 2010, 43, 9591-9593. [CrossRef]

19. Pan, Y.; Rong, W.; Jian, Z.; Cui, D. Ligands dominate highly syndioselective polymerization of styrene by using constrained-geometry-configuration rare-earth metal precursors. Macromolecules 2012, 45, 1248-1253. [CrossRef]

20. Natta, G.; Pino, P.; Corradini, P.; Danusso, F.; Mantica, E.; Mazzanti, G.; Moraglio, G. Crystalline high polymers of $\alpha$-olefins. J. Am. Chem. Soc. 1955, 77, 1708-1710. [CrossRef]

21. Natta, G.; Corradini, P. Kristallstruktur des isotaktischen polystyrols. Makromol. Chem. 1955, 16, 77-80. [CrossRef]

22. Overberger, C.; Mark, H. A convenient laboratory preparation of isotactic polystyrene. J. Polym. Sci. 1959, 35, 381-389. [CrossRef]

23. Kern, R.J.; Hurst, H.G.; Richard, W.J. Triethylaluminum-titanium tetrachloride catalysts for preparation of crystalline polystyrene. J. Polym. Sci. 1960, 45, 195-204. [CrossRef]

24. Xu, G.; Lin, S. A novel $\mathrm{NdCl}_{3}$-modified Ziegler-Natta catalyst for the isotactic-specific polymerization of styrene. Macromol. Rapid Commun. 1994, 15, 873-877. [CrossRef]

25. Rosário Riberio, M.; Portela, M.F.; Deffieux, A.; Cramail, H.; Rocha, M.F. Isospecific homo- and copolymerization of styrene with ethylene in the presence of $\mathrm{VCl}_{3}, \mathrm{AlCl}_{3}$ as catalyst. Macromol. Rapid Commun. 1996, 17, 461-469. [CrossRef]

26. Sun, Q.; Fan, Y.; Liao, S.; Liu, J.; Wan, F.; Xu, J. Isospecific polymerization of styrene with modified Ziegler-type catalysts. Polymer 2001, 42, 4087-4090. [CrossRef]

27. Kern, R.J. Homogeneous synthesis of isotactic polystyrene using n-butyllithium initiator. Nature 1960, 187, 410. [CrossRef]

28. Cazzaniga, L.; Cohen, R.E. Anionic synthesis of isotactic polystyrene. Macromolecules 1989, 22, 4125-4128. [CrossRef]

29. Makino, T.; Hogen-Esch, T.E. Anionic synthesis of highly isotactic polystyrene in hexane in the presence of lithium hydroxides. Macromolecules 1999, 32, 5712-5714. [CrossRef]

30. Maréchal, J.-M.; Carlotti, S.; Shcheglova, L.; Deffieux, A. Stereospecific anionic polymerization of styrene initiated by $\mathrm{R}_{2} \mathrm{Mg} / \mathrm{ROMt}$ 'ate' complexes. Polymer 2004, 45, 4641-4646. [CrossRef]

31. Ascenso, J.R.; Dias, A.R.; Gomes, P.T.; Romao, C.C.; Tkatchenko, I.; Revillon, A.; Pham, Q.T. Isospecific oligo-/polymerization of styrene with soluble cationic nickel complexes. The influence of phosphorus(III) ligands. Macromolecules 1996, 29, 4172-4179. [CrossRef] 
32. Crossetti, G.L.; Bormioli, C.; Ripa, A.; Giarrusso, A.; Porri, L. Polymerization of styrene to isotactic polymer with MAO-Ni(acac) 2 . Examination of the factors that influence activity and stereospecificity. Macromol. Rapid Commun. 1997, 18, 801-808. [CrossRef]

33. Po, R.; Cardi, N.; Santi, R.; Romano, A.M.; Zannoni, C.; Spera, S. Polymerization of styrene with nickel complex/methylaluminoxane catalytic systems. J. Polym. Sci., Part A Polym. Chem. 1998, 36, 2119-2126. [CrossRef]

34. Arai, T.; Ohtsu, T.; Suzuki, S. Homo- and copolymerization of styrene by bridged zirconocene complexes with benzindenyl ligands. Polym. Prepr. 1998, 39, 220-221.

35. Arai, T.; Suzuki, S.; Ohtsu, T. Homo- and copolymerization of styrene by bridged zirconocene complex with benz indenyl ligand. ACS Symp. Ser. 2009, 749, 66-80.

36. Capacchione, C.; Proto, A.; Ebeling, H.; Mülhaupt, R.; Möller, K.; Spaniol, T.P.; Okuda, J. Ancillary ligand effect on single-site styrene polymerization: Isospecificity of Group 4 metal bis(phenolate) catalysts. J. Am. Chem. Soc. 2003, 125, 4964-4965. [CrossRef] [PubMed]

37. Capacchione, C.; Manivannan, R.; Barone, M.; Beckerle, K.; Centore, R.; Oliva, L.; Proto, A.; Tuzi, A.; Spaniol, T.P.; Okuda, J. Isospecific styrene polymerization by chiral titanium complexes that contain a tetradentate [OSSO]-Type bis(phenolato) ligand. Organometallics 2005, 24, 2971-2982. [CrossRef]

38. Hohberger, C.; Spaniol, T.P.; Okuda, J. Living polymerization by bis(phenolate) zirconium catalysts: Synthesis of isotactic polystyrene-block-polybutadiene copolymers. Macromol. Chem. Phys. 2014, 215, 2001-2006. [CrossRef]

39. Proto, A.; Avagliano, A.; Saviello, D.; Ricciardi, R.; Capacchione, C. Living, isoselective polymerization of styrene and formation of stereoregular block copolymers via sequential monomer addition. Macromolecules 2010, 43, 5919-5921. [CrossRef]

40. Capacchione, C.; Saviello, D.; Ricciardi, R.; Proto, A. Living, isoselective polymerization of 4-methyl-1,3-pentadiene and styrenic monomers and synthesis of highly stereoregular block copolymers via sequential monomer addition. Macromolecules 2011, 44, 7940-7947. [CrossRef]

41. Rodrigues, A.-S.; Kirillov, E.; Roisnel, T.; Razavi, A.; Vuillemin, B.; Carpentier, J.-F. Highly isospecific styrene polymerization catalyzed by single-component bridged bis(indenyl) allyl yttrium and neodymium complexes. Angew. Chem., Int. Ed. 2007, 46, 7240-7243. [CrossRef] [PubMed]

42. Annunziata, L.; Rodrigues, A.-S.; Kirillov, E.; Sarazin, Y.; Okuda, J.; Perrin, L.; Maron, L.; Carpentier, J.-F. Isoselective styrene polymerization catalyzed by ansa-bis(indenyl) allyl rare earth complexes. Stereochemical and mechanistic aspects. Macromolecules 2011, 44, 3312-3322. [CrossRef]

43. Nakata, N.; Toda, T.; Ishii, A. Recent advances in the chemistry of Group 4 metal complexes incorporating [OSSO]-type bis(phenolato) ligands as post-metallocene catalysts. Polym. Chem. 2011, 2, 1597-1610. [CrossRef]

44. Nakata, N.; Ishii, A. Precise polymerization of $\alpha$-olefins using a mixed donor-type ligand containing oxygen and sulfur atoms. Koubunshi Ronbunshu 2015, 72, 285-294. [CrossRef]

45. Toda, T.; Nakata, N.; Matsuo, T.; Ishii, A. Synthesis and structures of dialkyl zirconium complexes with an [OSSO]-type bis(phenolate) ligand bearing a trans-1,2-cyclooctanediylbis(thio) unit. J. Organomet. Chem. 2011, 696, 1258-1261. [CrossRef]

46. Nakata, N.; Toda, T.; Ishii, A.; Matsuo, T. Titanium complexes supported by an [OSSO]-Type bis(phenolato) ligand based on a trans-cyclooctanediyl platform: Synthesis, structures, and 1-hexene polymerization. Inorg. Chem. 2012, 51, 274-281. [CrossRef] [PubMed]

47. Toda, T.; Nakata, N.; Ishii, A.; Matsuo, T. Synthesis, structure, and 1-hexene polymerization catalytic ability of Group 5 metal complexes incorporating an [OSSO]-type ligand. ACS Catal. 2013, 3, 1764-1767. [CrossRef]

48. Nakata, N.; Saito, Y.; Ishii, A. Neutral methyl and cationic aluminum complexes supported by a trans-1,2-cyclooctanediyl-bridged [OSSO]-type bis(phenolato) ligand: Synthesis, structures, and use in catalysis for propylene oxide polymerization. Organometallics 2014, 33, 1840-1844. [CrossRef]

49. Ishii, A.; Toda, T.; Nakata, N.; Matsuo, T. Zirconium complex of an [OSSO]-type diphenolate ligand bearing trans-1,2-cyclooctanediylbis(thio) core: Synthesis, structure, and isospecific 1-hexene polymerization. J. Am. Chem. Soc. 2009, 131, 13566-13567. [CrossRef] [PubMed]

50. Toda, T.; Nakata, N.; Matsuo, T.; Ishii, A. Extremely active $\alpha$-olefin polymerization and copolymerization with ethylene catalyzed by a dMAO-activated zirconium(IV) dichloro complex having an [OSSO]-type ligand. RSC Adv. 2015, 8, 88826-88831. [CrossRef] 
51. Nakata, N.; Toda, T.; Matsuo, T.; Ishii, A. Controlled isospecific polymerization of $\alpha$-olefins by hafnium complex incorporating with a trans-cyclooctanediyl-bridged [OSSO]-type bis(phenolate) ligand. Macromolecules 2013, 46, 6758-6764. [CrossRef]

52. Nakata, N.; Saito, Y.; Watanabe, T.; Ishii, A. Completely isospecific polymerization of 1-hexene catalyzed by hafnium(IV) dichloro complex incorporating with an [OSSO]-type bis(phenolate) ligand. Top. Catal. 2014, 57, 918-922. [CrossRef]

53. Takano, M.; Ito, K.; Ishii, A.; Nakata, N.; Kawauchi, F. Jpn. Kokai Tokkyo Koho JP 2013166735, 29 August 2013.

54. Hasan, T.; Ioku, A.; Nishii, K.; Shiono, T.; Ikeda, T. Syndiospecific living polymerization of propene with [t-BuNSiMe ${ }_{2}$ Flu]TiMe 2 using MAO as cocatalyst. Macromolecules 2001, 34, 3142-3145. [CrossRef]

55. Rong, Y.; Al-Harbi, A.; Parkin, G. Highly variable $\mathrm{Zr}-\mathrm{CH}_{2}-\mathrm{Ph}$ bond angles in tetrabenzylzirconium: Analysis of benzyl ligand coordination modes. Organometallics 2012, 31, 8208-8217. [CrossRef]

56. Sheldrick, G.M. SHELXL-97. In Program for Crystal Structure Refinement; University of Göttingen: Göttingen, Germany, 1997.

57. Cohen, A.; Yeori, A.; Goldberg, I.; Kol, M. Group 4 complexes of a new [OSSO]-Type dianionic ligand. Coordination chemistry and preliminary polymerization catalysis studies. Inorg. Chem. 2007, 46, 8114-8116. [CrossRef] [PubMed]

58. Cohen, A.; Goldberg, I.; Venditto, V.; Kol, M. Oscillating non-metallocenes-From stereoblock-isotactic polypropylene to isotactic polypropylene via zirconium and hafnium dithiodiphenolate catalysts. Eur. J. Inorg. Chem. 2011, 5219-5223. [CrossRef]

59. Buffet, J.-C.; Okuda, J. Group 4 metal initiators for the controlled stereoselective polymerization of lactide monomers. Chem. Commun. 2011, 47, 4796-4798. [CrossRef] [PubMed]

60. Wang, X.; Thevenon, A.; Brosmer, J.L.; Yu, I.; Khan, S.I.; Mehrkhodavandi, P.; Diaconescu, P.L. Redox control of Group 4 metal ring-opening polymerization activity toward L-lactide and $\varepsilon$-caprolactone. J. Am. Chem. Soc. 2014, 136, 11264-11267. [CrossRef] [PubMed]

61. Konkol, M.; Nabika, M.; Kohno, T.; Hino, T.; Miyatake, T. Synthesis, structure and $\alpha$-olefin polymerization activity of Group 4 metal complexes with [OSSO]-type bis(phenolate) ligands. J. Organomet. Chem. 2011, 696, 1792-1802. [CrossRef]

(c) 2016 by the authors; licensee MDPI, Basel, Switzerland. This article is an open access article distributed under the terms and conditions of the Creative Commons by Attribution (CC-BY) license (http://creativecommons.org/licenses/by/4.0/). 